\title{
EFFICIENCY OF BACTERIZATION AND MINERAL FERTILIZERS ON CUCURBITS IN SOUTHERN STEPPE OF UKRAINE
}

\author{
V. A. Lymar ${ }^{1}$, V. Ye. Dyshlyuk ${ }^{2}$, V. O. Podpryadov ${ }^{1}$, P. A. Marchuk ${ }^{1}$ \\ ${ }^{1}$ Southern State Agricultural Experiment Station, Institute of Water Problems and Land \\ Reclamation, NAAS, Hola Prystan \\ 71, Chervonoarmiiska Str., Hola Prystan Town, Kherson region, 75600, Ukraine; \\ e-mail: ipobuaan@gmail.com \\ ${ }^{2}$ National Academy of Agrarian Sciences of Ukraine, Kyiv \\ 37, Vasylkivska Str., Kyiv City, 03022, Ukraine; e-mail: dishlyuk@yandex.ru
}

Recently, the matter of environmental degradation of planetary character and associated production of quality food has been discussed in the literature. Reported are adverse effects of technological intensification of agriculture and the need for greening of agriculture $[1 ; 2]$. In particular, it is pointed to the need for the introduction of biological agriculture. One of the major features of this direction is the optimization of biological processes in soil agrocenoses for rational use of nutrients in plant nutrition [24]. According to some researchers [3; 4], it is extremely important to search for ways to maximize biological fixation of atmospheric nitrogen. One of the most powerful factors of intensifying the process of nitrogen fixation and optimization of production process of crops is the use of preparations based on live cultures of agronomically valuable microorganisms. Modern microbial preparations allow to minimize the level of chemicals in soil agrocenoses and, thus, the risk of contamination of plant production and the environment. In recent years the methodology and practice of using microbial preparations in the technologies of growing leading crops has been worked out [3-7].

It is known [8] that the realization of the potential of modern varieties of gourds is possible only if optimal plant nutrition is ensured, nutrients are present in soil and they are available to plants. Important here is the activation and intensification of certain biological processes in rhizospheric soil to provide a plant with available forms of nutrient compounds. The availability of nutrients is significantly influenced by metabolic activity of rhizospheric microorganisms that allows to schedule reducing the dose of fertilizers. Studies [3-7] established the effectiveness of combined application of microbial preparations and mineral fertilizers in growing many crops. As for the efficiency of use of this agronomical practice in growing gourds, such data is not available in the literature, except for a few reports concerning the cultivation of watermelon $[9 ; 10]$. The study of the efficiency of this agronomical practice in growing squash has not been conducted. Meanwhile, there is a pressing need for this, because in recent years an increase in the area under this crop up to 25 thousand ha has been observed $[11 ; 12]$. It is only in Kherson region that the crop is grown on 10 thousand ha. Squash fruits are an important food product, which, in addition to nutritious, has therapeutic properties [8]. However, due to the lack of environmentally attractive production technologies and a number of other reasons, the needs for this product in the country do not meet scientifically-grounded standards [11], which is one of negative elements in shaping nation's health.

The goal of the study was to establish the efficiency of microbial preparations in growing technologies for cucurbit considering agricultural backgrounds.

Materials and methods. The study was conducted in 2009-2011 in bogharic conditions in the stationary field experiment, laid in State enterprise Experiment Farm "Velyki Klyny" of Southern State Agricultural Experiment Station of the Institute of Water Problems and Land Reclamation of NAAS. Soil - solodic black earth soil of sabulous granulometric texture. The content of humus in the topsoil - 1.0$1.2 \%$; $\mathrm{pH}$ 6.8-7.2; gross forms content (\%): $\mathrm{N}$ $-0.012-0.016, \mathrm{P}_{2} \mathrm{O}_{5}-0.038-0.045, \mathrm{~K}_{2} \mathrm{O}-$ 0.55-0.67 and movable forms (mg/100 g): nitrates - 0.35-0.76, phosphorus - 3.5-5.5, exchangeable potassium - 28.0-38.5. Parent rock material - loess loam. 
Cucurbit of Hilea variety was grown. Cultivated area $-150 \mathrm{~m}^{2}$, record plot -120 $\mathrm{m}^{2}$. The area under the experiment -1.0 ha. Repetition of the experiments - quadruple. Number of record plants - 40. Planting system (plant nutrition area) $-2.1 \mathrm{~m} \mathrm{x} 1.4 \mathrm{~m}$ (2.94 $\mathrm{m}^{2}$ per plant). Two-factor experiment: A factor - bacterization (preplant treatment of seeds with microbial preparations) and factor B - agricultural backgrounds (without fertilizers; recommended dose of fertilizers $\left(\mathrm{N}_{60} \mathrm{P}_{90} \mathrm{~K}_{60}\right)$ applied in bulk (overall), 50\% of the recommended dose of fertilizers $\mathrm{N}_{30} \mathrm{P}_{45} \mathrm{~K}_{30}$ (applied locally in the row), 30\% of the recommended dose of fertilizers $\mathrm{N}_{20} \mathrm{P}_{30} \mathrm{~K}_{20}$ (applied locally in the row). The overall application of fertilizers (in bulk) was provided by the following unit: tractor MTZ$82+$ lift-type fertilizer spreader HPY-0,5 (NRU-0.5), local (in the row) correspondingly tractor MTZ-82 + cultivator-fertilizer KPH4,2 (KRN-4.2). Microbial preparations (Biogran - integrated microbial preparation including nitrogen-fixation bacteria Azotobacter and physiologically active substances of natural origin; Azotobacterin on the basis of bacteria of Azotobacter genus; Albobacterin - based on phosphate-mobilizing bacteria Achromobacter album 1122) are produced at the Institute of Agricultural Microbiology and Agroindustrial Manufacture, NAAS. Azotobacterin and Albobacterin were used for preplant bacterization at the rate of $40-50 \mathrm{ml}$ of suspension per 1 hectare seed rate. Granulated microbial preparation Biogran was applied into soil locally in the row at sowing by the unit: tractor MTZ-82 + cultivator-fertilizer KPH-4,2 (KRN-4.2).

Farming culture is zonal, except investigated agronomical practices. Precursor - winter wheat. Record of harvest was carried out during the onset of full ripeness of fruits. The study was performed using the following methods: soil sampling - by DSTU 4287:2004, soil biological activity determination - by Shtatnovyi [13], potential activity of nitrogen fixation process in the soil [14], nitrates content - colorimetrically with phenoldisulfonic acid by Grandval-Lajoux (GOST 26951-86), movable phosphorus - by Machyhin (DSTU 4115-2002), exchangeable potassium - in $1 \%$ ammonium extract at flame photometer (DSTU 4115-2002), leaf surface area - by O. Ya. Kashcheiev [15], crop record - by a direct method with distribution of fruits by fractions [16], dry matter content in fruits - by refractometric method [16], sugars - by Bertrand micromethod modified by Bierry by cyanide method (GOST 8756 13-87), ascorbic acid by Murray method (GOST 24556-89), nitrates - by potentiometric method (GOST 5048-89). Mathematical processing of the results was performed by dispersion method [17]. Experiments initiation, conduct of observations and records during crop growing season were performed according to the methods of research in vegetable and melon growing [16] and methods of selection process and conducting field experiments with gourds [18].

Agrometeorological conditions in 2009-2011 differed from each other that caused certain features of their effects on cucurbit plants growing and development.

When applying Azotobacterin and Albobacterin for preplant bacterization, as well as variants without seeds bacterization and growing crops at different agricultural backgrounds, other than the above, the nitrate content in fruits was significantly higher (1.6, 1.3 and 1.3 times, respectively). Thus, we can conclude that the use of microbial preparations for bacterization of cucurbit seeds promotes improving production quality indicators of this gourd crop, which is consistent with the data obtained before at growing watermelon [10].

Our calculations show that the highest production profitability rates for cucurbit fruits $(70.4 \%)$ were received at their growing after seed bacterization with Azotobacterin on the background of application of $50 \%$ of the recommended dose of fertilizers $\left(\mathrm{N}_{30} \mathrm{P}_{45} \mathrm{~K}_{30}\right)$ with its local application. At this, fertilizers payback is 59.0 UAH (table 6). At this variant the lowest cost of grown products was detected - 264.1 UAH/t of fruits.

According to the research scientists of the station improved the technology of cucurbit growing by optimizing amounts of fertilizer necessary for normal development of plants with increased intensity of nitrogen fixation in rhizospheric soil [19], which makes it possible to lower the amounts of nitrogen fertilizers and increase the availability of nitrogen in critical for cucurbit 
growth periods. Using Azotobacterin, optimal dose of mineral fertilizers is $\mathrm{N}_{30} \mathrm{P}_{45} \mathrm{~K}_{30}$. The efficiency of the improved technology of cucurbit growing was tested and implemented at the steppe zone agricultural enterprises on the Southern low-humic sabulous black soil in the conditions of bogharic agriculture. It was established that the application of the proposed technology increased the yield of cucurbit of Hilea variety up to $20 \%$ compared to the indicators when basic technology is used.

With this product indicators increased: as a result of activation of plant enzyme systems solid content increased to $7.5 \%$,
Vitamin C - to $6.5 \mathrm{mg} / 100 \mathrm{~g}$, sugars - to $7 \%$, carotene - up to $20 \%$. The content of amino acids and protein also increased, while the amount of nitrates in products decreased to 30 $\mathrm{mg} / \mathrm{kg}$. In addition, prevalence of fruit with pathogens of fungal diseases decreased. Due to the use of advanced technology in the production conditions on the area of 90 hectares at Station's subordinate State enterprise Experiment Farm "Velyki Klyny" crop productivity increased by $15 \%$, production profitability - by $42 \%$ [19]. Proprietary right for the development is secured by the Patent of Ukraine for utility model No. 93382 [20]. 